\section{OPEN ACCESS}

Edited by:

Yasuyuki Goto,

The University of Tokyo, Japan

Reviewed by:

Prosper N. Boyaka,

The Ohio State University,

United States

Hajime Karasuyama,

Tokyo Medical and Dental University,

Japan

*Correspondence:

Steven F. Ziegler

sziegler@benaroyaresearch.org

Specialty section:

This article was submitted to

Microbial Immunology,

a section of the journal

Frontiers in Immunology

Received: 15 July 2020

Accepted: 23 October 2020

Published: 27 November 2020

Citation:

Obata-Ninomiya K, Domeier P and

Ziegler SF (2020) Basophils and

Eosinophils in Nematode Infections.

Front. Immunol. 11:583824.

doi: 10.3389/fimmu.2020.583824

\title{
Basophils and Eosinophils in Nematode Infections
}

\author{
Kazushige Obata-Ninomiya ${ }^{1}$, Phillip P. Domeier ${ }^{1}$ and Steven F. Ziegler ${ }^{1,2 *}$ \\ 1 Immunology Program, Benaroya Research Institute, Seattle, WA, United States, ${ }^{2}$ Department of Immunology, University of \\ Washington School of Medicine, Seattle, WA, United States
}

Helminths remain one of the most prolific pathogens in the world. Following infection helminths interact with various epithelial cell surfaces, including skin, lung, and gut. Recent works have shown that epithelial cells produce a series of cytokines such as TSLP, IL-33, and IL-25 that lead to the induction of innate and acquired type 2 immune responses, which we named Type 2 epithelial cytokines. Although basophils and eosinophils are relatively rare granulocytes under normal conditions $(0.5 \%$ and $5 \%$ in peripheral blood, respectively), both are found with increased frequency in type 2 immunity, including allergy and helminth infections. Recent reports showed that basophils and eosinophils not only express effector functions in type 2 immune reactions, but also manipulate the response toward helminths. Furthermore, basophils and eosinophils play non-redundant roles in distinct responses against various nematodes, providing the potential to intervene at different stages of nematode infection. These findings would be helpful to establish vaccination or therapeutic drugs against nematode infections.

Keywords: helminth, nematode, allergy, basophil, eosinophil, Th2, type 2 immunity, Type 2 epithelial cytokines

\section{INTRODUCTION}

Basophils and eosinophils, first described by Paul Ehlrich in 1879, are granulocytes $(1,2)$. Basophils and eosinophils are relatively rare when compared to other leukocytes. Basophils and eosinophils predominantly exist at most $0.5 \%$ and $5 \%$, respectively, in peripheral blood under normal conditions, and have short half-lives when compared to lymphocytes. Intriguingly, basophils and eosinophils are evolutionally conserved in many animal species, suggesting their crucial and beneficial roles in vivo.

Basophils share some features with tissue-resident mast cells, which are abundant in peripheral tissues and long-lived cells. Basophils and mast cells are characterized by the expression of basophilic granules, surface expression of FcERI, a high affinity IgE receptor, and release of chemical mediators (i.e., histamine) in response to cross-linking of surface IgE binding to FceRI by antigens. Eosinophils have eosinophilic granules that contain eosinophil peroxidase (EPO), major basic protein, ribonulease cationic protein and eosinophil-derived neurotoxin, which are associated with allergic disorders and protection against parasites. In addition, Interleukin-5 receptor subunit- $\alpha$ on eosinophils define their unique biology in response to IL- 5 produced by ILC2 and memory Th2 cells. Despite rarities of basophils and eosinophils in homeostatic conditions, basophils and eosinophils are found with increased their frequencies in peripheral tissues and play nonredundant roles in type 2 immune responses such as allergic inflammation and helminth infections. In the past 15 years, several works using deficient mice and specific-Cre mice 
for basophils or eosinophils characterized the indispensable roles of basophils and eosinophils in pathophisiology. In this review, we summarize the latest research on the pivotal and nonredundant roles of basophils and eosinophils in nematode infection. This review would be helpful to establish vaccination or therapeutic drugs against nematode infections.

\section{DEVELOPMENT OF BASOPHILS AND EOSINOPHILS}

Granulocytes develop from pluripotent $\mathrm{CD} 34^{+}$granulocyte progenitor (GP) cells in bone marrow through granulocyte/ monocye progenitors (GMPs). GMPs derive the eosinophil lineage-committed progenitors (EoPs), and pre-basophil and mast cell progenitors (pre-BMPs) in bone marrow and the basophil/mast cell progenitors (BMCPs) in spleen. The pre$\mathrm{BMPs}$ and BMCPs give rise to the mast cell progenitors (MCPs) and the basophil progenitors (BaPs) $(3,4)$ Controversially, Mukai et al. mentioned that BMCPs developed into mast cells, and not into basophils (5). The differentiation of basophils is regulated by Signal transducer and activator of transcription 5 (STAT5), the transcription factor distal promoter-derived Runt-related transcription factor 1 (Runx1), Interferon Regulatory factor 8 (IRF8), GATA binding protein 1 (GATA-1), GATA-2, and CCAAT/Enhancer Binding Protein $\alpha$ $(\mathrm{C} / \mathrm{EBP} \alpha)(5-10)$. STAT5 signaling is required for the differentiation of pre-BMPs into both basophils and mast cells through induction of GATA2, $\mathrm{C} / \mathrm{EBP} \alpha$, and MicrophthalmiaAssociated Transcription Factor (MITF) that is important for differentiation of mast cells. Runx1-deficient mice exhibit a reduction of BaPs and basophils. Expression of IRF8 in GPs that assumingly develop from GMP to give rise to pre-BMP and BMCPs, is important for development of basophils upstream of GATA-2. The differentiation of eosinophils is regulated by GATA binding protein 1 (GATA-1), PU.1, and the CCAAT-enhancing binding protein (c/EBP) family of transcription factors. GATA-1 and PU.1 synergistically promote transcription of major basic protein (MBP). The absence of both MBP and EPO resulted in near complete loss of eosinophils in vivo (11).

GATA-1 reprograms immature myeloid cells to develop three different hematopoietic progenitor lineages: erythroid cells, megakaryocytes and granulocytes. GATA-1 is essential for maturation of erythroid and megakaryocyte precursors and positive autoregulation of GATA-1 expression is mediated by high affinity palindromic GATA-binding sites in the GATA-1 promoter $(12,13)$. Deletion of these GATA-binding sites in mice (called $\Delta$ dblGATA mice) results in a complete ablation of mature eosinophils (14). $\Delta$ dblGATA mice exhibit normal platelet development, and red blood cell production is only subtly impaired, but GATA-1 null mice have an embryonic lethal phenotype, with profound anemia and defective megakaryocyte development. As a result of these findings, $\Delta$ dblGATA mice were used as model of "eosinophil-deficient" mice, but later studies have defined additional roles for GATA-1 in the development of basophils and mast cells (15). GATA-1 expression is involved in the development and activity of megakaryocyte/erythrocyte progenitors, basophil/mast cell progenitors, basophil progenitors, mast cell progenitors and eosinophil progenitors but not granulocyte/monocyte progenitors (16-19). More recent studies have shown that $\triangle$ dblGATA mice exhibit additional defects in the generation of basophil precursor cells $(\mathrm{BaP})$ and mature basophils $(3,20)$. Furthermore, basophils that do develop in $\triangle$ dblGATA mice have impaired IL-4 production and CD63 expression after cross-linking of antigen-specific IgE. Knockdown of GATA-1 in basophils in vitro resulted in defective basophil development, reduced degranulation and lower production of IL- 4 in response to antigen stimulation. These suggested that defects in basophils of $\Delta$ dblGATA mice are due to decreased expression of GATA-1. In contrast to basophils, mast cell development in $\triangle$ dblGATA mice is not overtly impacted $(21,22)$. Similar to this, GATA-1-deletion does not affect development of mast cells in vivo and in vitro $(23,24)$. Collectively, $\Delta$ dblGATA mice showed developmental and functional impairments in basophils and eosinophils. In addition, the transcription factor GATA-1 controls both basophils and eosinophils.

\section{BASOPHILS}

\section{Basophilia in Parasite Infection}

Although basophils make up a small proportion $(<0.5 \%)$ of leukocytes in the blood, they accumulate in peripheral tissues during type 2 inflammation. Infiltration of basophils is observed in local lesions after helminth infection, and allergic skin diseases, implying that they may play important roles in supporting the inflammation $(25,26)$. Similar to allergic diseases, basophils accumulate in skin lesions of humans and mice after infestation with ectoparasites (27-29). However, unlike mice, blood basophilia rarely occurs in humans following nematode infections (30).

$\mathrm{CD}^{+} \mathrm{T}$ cell-derived IL-3 is critical for the survival and proliferation of basophils during a nematode infection (31). IL-3 activates basophils to produce IL- 4 through IL-3R $\alpha$ chain and FcR $\gamma$ chain complex (32). Thymic stromal lymphopoietin (TSLP) induced by helminth infection, supports basophil proliferation and promotes induction of Th2 cytokine responses in Trichinella infection (33). During Heligmosomoides polygyrus (Hp) infection, IL-3, IgG1, and IgE selectively promote basophil expansion (34). IgE signaling promotes IL-3R $\alpha$ chain expression on basophils (35). The factors that drive basophil expansion downstream of the IgE/FceRI axis are still unknown. In mast cells, IgE induces survival via binding to FceRI on mast cells by signaling through Bfl-1, a Bcl-2 family protein. However, the IgE/FceRI/Bfl-1 axis apparently is not operative in human basophils $(36,37)$.

\section{Basophils and Type 2 Epithelial Cytokines}

TSLP, IL-33, and IL-25 are predominantly produced from barrier epithelial cells to initiate type 2 immune responses, including eosinophilia. Thus, they are referred to as Type 2 epithelial cytokines. 
Basophils express receptors for TSLP and IL-33 (38). TSLP activates basophils to produce IL-4, resulted in establishment of Th2 cell-dependent immunity (38). IL-33 activates basophils and mast cells to enhance the degranulation and production of cytokines such as IL-4, IL-6, and IL-13 (39). IL-33-mediated basophil activation has been discussed in atopic dermatitis (40). Single Nucleotide Polymorphisms (SNPs) in both TSLP and CRLF2 coding TSLP receptor result in increased expression or signaling, and have been associated with Eosinophilic esophagitis (EoE) (41). In addition, IL-33 cytokine and receptor (IL1RL1, ST2) signaling is elevated in gastrointestinal allergic diseases, including food allergy and EoE (42). Of note, ST2 expression on basophils is necessary for basophil accumulation in the esophagus and the development of experimental EoE. Basophils are also required for TSLP-mediated EoE and IL-33mediated food allergy in mice $(43,44)$.

The role of basophils in TSLP-dependent inflammation has been studied well, using topical vitamin D3 analog (MC903)induced model of atopic dermatitis. Basophil-specific IL-4deficient mice (IL-4 3'UTR mice) exhibit impaired ear swelling, reduced levels of antigen-specific serum $\operatorname{IgE}$ and diminished production of type 2 cytokines in lymph nodes after topical MC903 treatment (21). In addition, TSLP-stimulated basophils enhance ILC2 responses through production of IL-4, resulting in skin inflammation (45). However, basophil-specific TSLPRdeficiency by bone marrow chimerism does not confer protection from cutaneous inflammation or limit serum IgE titers after topical MC903 treatment (46). Furthermore, Basophil-specific TSLPR-deficiency in $M c p t 8^{c r e} T s l p f^{f l f l}$ mice, did not impair the severity of the airway inflammation, generation of Th2 cells or levels of serum IgE when compared to control mice after intranasal challenges of antigen with MC903, suggesting that this type 2 inflammatory response was mediated by TSLPR on DC and $\mathrm{CD}^{+} \mathrm{T}$ cells, but not basophils and ILC2 cells (47).

\section{Basophils and Th2 Differentiation in Helminth Infection}

Basophils promote Th2 cell differentiation through IL-4 production during Trichinella spiraris (Ts), Heligmosomoides polygyrus $(\mathrm{Hp})$ and Litomosomoides sigmodontis Filaria infections $(33,48,49)$. Giacomin et al. showed that deficiency of TSLPR, but not IL-3R, impaired basophilia in draining lymph nodes during Ts infection, which is associated with reduction of Th2 cells. Also, Th2 cell-mediated immune responses are important for expulsion of Hp parasites during re-infection (50).

Naïve $\mathrm{CD}^{+} \mathrm{T}$ cells require the interaction with peptideloaded MHC class II (MHC-II) complexes on antigen presenting cells (APCs) to differentiate into Th2 cells, so Th2-differentiation could be primed by basophils. Pioneering work by Hida et al. showed that basophils produce IL-4 to support APCs, and promote Th2 cell differentiation (51). This finding was supported by follow-up studies from other research groups (52, 53). Later, three independent groups observed that basophils express MHC-II and secrete IL-4 to induce the differentiation of naïve $\mathrm{CD}^{+} \mathrm{T}$ cells to $\mathrm{Th} 2$ cells. Furthermore, depletion of basophils by anti-FceRI $\alpha$ antibody (clone MAR-1) diminished Th2 cell differentiation in vivo. These findings suggest that basophils are professional APCs that express peptide-loaded MHC-II, induce Th2 differentiation in a cysteine protease papain-administration model, IgE and antigen-induced model and Trichuris muris (Tm) in primary infection (54-56). Yoshimoto et al. also showed that human basophils express MHC-II in that paper. However, the role of basophils as APCs is still under discussion. (1) Although all three papers used antiFceRI $\alpha$ antibody MAR-1 antibodies to deplete basophils in vivo, recent work revealed that MAR-1 binding is not limited to FceRI $\alpha$, but this antibody can also non-specifically bind to Fc $\gamma$ RI and Fc $\gamma$ RIV (57). Furthermore, treatment of MAR-1 depletes CD11c inflammatory DC in vivo (57-59). (2) When compared to DCs and B cells, basophils express low levels of surface MHC-II. Basophils also do not express the proteins that are required for $\mathrm{MHC}$-II-restricted antigen processing or presentation, including cathepsin $\mathrm{S}, \mathrm{H}-2 \mathrm{M}$ and the invariant chain Ii, and they exhibit a minimal capacity to process and present antigen when compared with DCs (52, 53, 58, 59). Miyake et al. demonstrated that basophils acquire peptideMHC-II complexes from DCs via trogocytosis to prime Th2 cells in MC903 treatment-induced atopic dermatitis model (60). To resolve these remaining discrepancies, further studies will be needed to compare MHC-II functions on DCs and basophils with CD11c-Cre and basophil-specific Cre mice, respectively. Although some of basophil-specific Cre was based on a gene of $\mathrm{mMCP}-8$, the technical caveat is that $\mathrm{mMCP}-8$ expression is not restricted to basophils $(61,62)$.

Basophils are important for the expulsion of Tm from the cecum in primary infection. In the Tm model of helminth infection, Webb LM et al. showed that basophil localization to the caecum, but not the spleen, is regulated by Notch expression (63). Thus, Notch signaling in basophils is critical to induction of type 2 immune responses, including Th2 cell generation, RELM$\beta$ expression in cecum and resulting Tm clearance.

Recently, it has been reported that basophils can inhibit the type 2 immune responses via increase of expression of neuromedin B (NMB) receptors on ILC2 cells in primary infection of $\mathrm{Nb}$, suggesting that basophils are not always inducer or enhancer of Type 2 immune responses (64).

\section{Basophils and M2-Type Macrophages in Helminth Infection}

M2-type macrophages play key roles in regulating allergy and confer protective roles against helminths (50, 65-67). M2-type macrophages also protect against fatal lung damage in primary $\mathrm{Nb}$ infection (68).

Basophil depletion by Thy1.2 or CD200R3 antibody correlates with increased worm burden after re-infection with Nippostrongylus brasiliensis $(\mathrm{Nb})$ (69-71) (Figure $\mathbf{1}$ and Table 1), and this protection is mediated by basophil-derived type 2 cytokines (72). During $\mathrm{Nb}$ infection, cross-linking of $\mathrm{Nb}$ antigen-specific IgE promotes basophil activation and IL-4 production. Basophil-derived IL-4 promotes M2-type macrophage differentiation, and the production of anti-parasitic enzyme Arginase-1 to protect against 


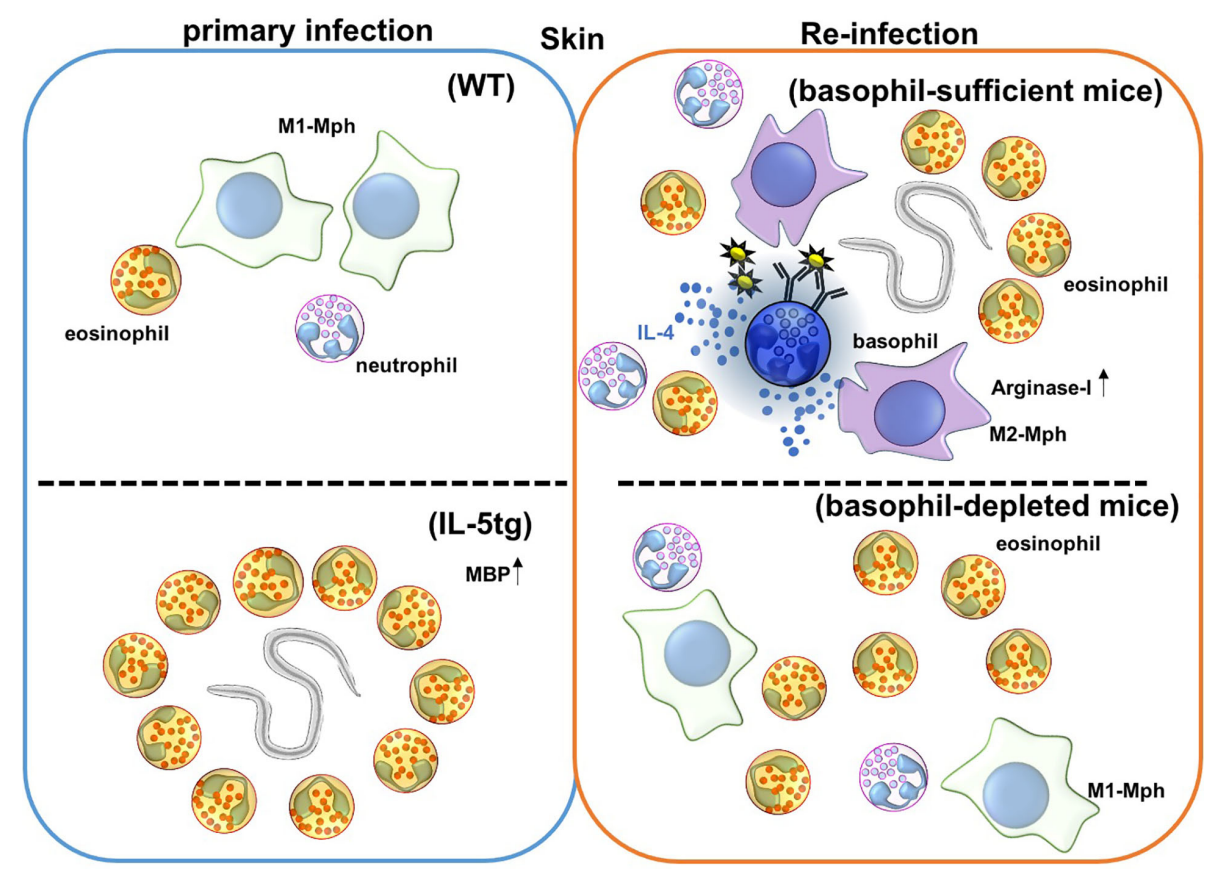

FIGURE 1 | Immune responses against Nippostrongylus brasiliensis (Nb) infection in the skin. Nb leaves the skin and enters the blood and lymphatic vessels within 20 minutes of primary infection. In IL-5 transgenic mice, eosinophils are activated by overexpression of IL-5, and produce the anti-helminthic enzyme, major basic protein (MBP), causing Nb parasites to arrest in the skin lesion during primary infection. However, Nb antigens activate basophils during secondary infection, and correspondingly activate monocytes/macrophages to promote M2-type macrophage differentiation. Activated M2-type macrophages then secrete the anti-nematode enzyme, Arginase-l. Eosinophils are also accumulated in the skin, but the role of these accumulated eosinophils is not yet known. Depletion of basophils allows for Nb parasites to leave the skin, but eosinophils still infiltrate the tissue during secondary infection.

secondary $\mathrm{Nb}$ infection in the skin (73). Similar to this, Depletion of macrophages expressing Relma that is a marker of M2-type macrophages increased worm burden in the lungs and gut (68). Conversely, basophil-deficiency did not affect the protection against a secondary subcutaneous inoculation of Strongyloides venezuelensis (Sv) or Strongyloides ratti (Sr), which originally penetrate skin to infect the hosts by a mechanism that is similar to $\mathrm{Nb}(74-76)$

(Table 2).

TABLE 1 | The experimental models of nematode infections.

\begin{tabular}{|c|c|c|c|c|c|}
\hline Helminth & $\begin{array}{l}\text { Infection } \\
\text { stage }\end{array}$ & $\begin{array}{l}\text { Natural Route of } \\
\text { infection }\end{array}$ & $\begin{array}{l}\text { Route of } \\
\text { Experimental } \\
\text { inoculation }\end{array}$ & Characteristics of Infection & $\begin{array}{l}\text { Model for infection in human } \\
\quad \text { (infection route) }\end{array}$ \\
\hline $\begin{array}{l}\text { Nippostrongylus } \\
\text { brasiliensis }\end{array}$ & L3 larvae & Skin penetration & i.d., s.c. & $\begin{array}{l}\text { Naturally penetrate the skin and } \\
\text { migrate to the lungs. Parasites } \\
\text { then migrate to the gut to lay }\end{array}$ & $\begin{array}{l}\text { Ascaris lumbricoides (Oral ingestion) } \\
\text { Hookworms; } \\
\text { Necator americanus (Oral ingestion), }\end{array}$ \\
\hline $\begin{array}{l}\text { Strongyloides } \\
\text { venezuelensis }\end{array}$ & L3 larvae & Skin penetration & S.c. & eggs. Short-lived infection & $\begin{array}{l}\text { Ancylostoma duodenale } \\
\text { (Oral ingestion or skin penetration) }\end{array}$ \\
\hline Strongyloides ratti & & & & & Strongyloides stercolaris (Skin penetration) \\
\hline $\begin{array}{l}\text { Heligmosomoides } \\
\text { polygyrus }\end{array}$ & L3 larvae & Oral ingestion & p.o. & $\begin{array}{l}\text { Chronic infection from ingestion of } \\
\text { larvae }\end{array}$ & \\
\hline Trichinella spiralis & L1 larvae & Oral ingestion & p.o. & $\begin{array}{l}\text { Food-borne (infective juvenile), } \\
\text { zoonotic parasite }\end{array}$ & Trichinella spiralis (Oral ingestion) \\
\hline Trichuris muris & Eggs & Oral ingestion & p.o. & $\begin{array}{l}\text { Ingestion of infectious eggs that } \\
\text { hatch in the cecum and colon }\end{array}$ & Trichuris trichiura (Oral ingestion) \\
\hline Litomosoides sigmodontis & L3 larvae & mite & S.c., mite & Chronic infection & Human filarial diseases; \\
\hline Brugia pahangi & L3 larvae & mosquito & s.c. & $\begin{array}{l}\text { Adult worms inhabit the pleural } \\
\text { cavity }\end{array}$ & $\begin{array}{l}\text { Brugia malayi, Brugia timori, } \\
\text { Wuchereria bancrofti } \\
\text { Onchocerca volvulus, } \\
\text { Loa loa }\end{array}$ \\
\hline
\end{tabular}


M2-type macrophages also provide protection against secondary infection of Heligmosomoides polygyrus (Hp), but M2-type macrophage differentiation during $\mathrm{Hp}$ infection is induced by IL-4 from CD4 ${ }^{+} \mathrm{T}$ cells in small intestine (50). However, the expression of FCR, IL-4 and IL-13 on basophils is required for Th2 cell priming, downstream M2-type macrophage differentiation and Hp worm clearance (48). Taken together, after surface-bound IgE is cross-linked by helminth-derived antigens, basophils produce IL-4 and IL-13 to induce M2-type macrophage differentiation, resulting in expulsion of $\mathrm{Nb}$ and $\mathrm{Hp}$ from the skin and small intestine.

Non-basophils can also produce type 2 cytokines to induce $\mathrm{M} 2$-type macrophages in protection against $\mathrm{Nb}$ re-infection in the lungs $(67,82)$. As described by Chen et al. neutrophils in $\mathrm{Nb}$-infected mice upregulated IL-13 transcripts in secondary infection, suggesting that neutrophils could promote M2-type macrophage activation in the lungs to clear $\mathrm{Nb}$ parasites (67). Conversely, another study showed that ILC2 and Th2 cells, but not neutrophils, could potentially induce M2-type macrophage activation to kill $\mathrm{Nb}$ at the lung during secondary infection (82).

\section{Basophil-Derived Proteases}

Basophil-derived proteases, including serine protease mouse mast cell protease- 8 (mMCP-8), and tryptase mMCP-11, play an important role in promoting skin inflammation $(83,84)$. The mMCP-11 increases vascular permeability, allowing for increased migration of basophils, eosiniophils, macrophages and neutrophils. Intriguingly, mMCP-11-deficiency ameliorates IgE-mediated chronic allergic inflammation in the skin. Furthermore, intradermal administration of mMCP-8, induces the production of $\mathrm{Cxcl} 1, \mathrm{Ccl} 2$, and $\mathrm{Ccl} 24$, which recruit neutrophils, monocytes, and eosinophils into the lesion. Similar to atopic dermatitis, $\mathrm{Nb}$ re-infection is characterized by increased numbers of neutrophils, macrophages, eosinophils and basophils in the skin lesion and high titers of $\operatorname{IgE}$ in the serum. However, the role of these proteases in anti-helminth immunity is not yet known.
Basophils are involved in resistance against both Strongyloides venezuelensis (Sv) and Strongyloides ratti (Sr) in primary infection $(75,76)$. The contributions of basophils in induction and expansion of Th2 cells are negligible, although those parasites are expelled by type 2 immune responses from small intestine. It might be possible that basophil-specific molecules such as mMCP-8 and mMCP-11 are associated with the protection against these nematodes.

\section{EOSINOPHIL}

Eosinophils make up about 5\% of leukocytes in peripheral blood, and have a short half-life in circulation. However, the number of circulating eosinophils are increased in patients with allergic diseases and helminth infections. Eosinophil granules contain major basic protein, eosinophil cationic protein, eosinophilic peroxidase and eosinophil-derived neurotoxin.

Approximately, $7-10 \%$ of the total protein content of human eosinophils consists of galectin-10, while mice do not contain a functional galectin-10 gene $(85,86)$. Upon Eosinophil activation, secreted galectin-10 protein forms aggregates, called CharcotLeyden crystals, at sites of inflammation. Charcot-Leyden crystals were first described as extracellular bipyramidal crystals in the airways of patients with asthma in 1853 by Charcot, and this observation was confirmed by Leyden in 1872 . However, the link between Charcot-Leyden crystals and eosinophilic airway disease and/or mucus production was largely forgotten for over 100 years. Recent work from Persson et al. showed that intratracheal administration of galectin-10 promoted the infiltration of neutrophils and monocytes, and Th2 cell priming (87).

GM-CSF, IL-3, and IL-5 accelerate the growth, maturation, survival, and activation of eosinophils. GM-CSF-deficient mice exhibit impaired recruitment of eosinophils to airways in a model of allergic airway. IL-5 deficiency is correlated with a 2to 3 -fold reduction in B-1 cells and eosinophils as compared control mice. However, the eosinophils that did develop in IL-5deficient mice were morphologically similar to eosinophils in

TABLE 2 | The role of basophils and eosinophils in nematode infections.

\begin{tabular}{|c|c|c|c|}
\hline Helminth & The role of Basophils & The role of eosinophils & Referenc \\
\hline $\begin{array}{l}\text { Nippostrongylus } \\
\text { brasiliensis }\end{array}$ & - Basophils protect from re-infection in the skin. & $\begin{array}{l}\text { - CXCR6 }{ }^{+} \mathrm{ST} 2^{+} \text {mTh2 cells facilitate eosinophilia in the } \\
\text { lungs to reduce the fecundity in the lungs in re-infection. }\end{array}$ & $(73)$ \\
\hline & & & $(77)$ \\
\hline $\begin{array}{l}\text { Strongyloides } \\
\text { venezuelensis }\end{array}$ & $\begin{array}{l}\text { - Basophil-depletion in Mcpt8DTR mice revealed small contribution of } \\
\text { basophils in primary infection and minor or no roles in secondary infection. }\end{array}$ & $\begin{array}{l}\text { - The duration of Sv was increased in } \Delta \mathrm{db} \text { IGATA mice in } \\
\text { primary infection (unpublished data) }\end{array}$ & $(75)$ \\
\hline & & & $(74)$ \\
\hline \multirow[t]{2}{*}{ Strongyloides ratti } & - The number of intestinal nematodes and fecal eggs is elevated in Mcpt8- & - IL-5 deficiency increased the number of intestinal & (76) \\
\hline & Cre mice. & worms and fecal eggs. & $(78)$ \\
\hline \multirow[t]{2}{*}{$\begin{array}{l}\text { Heligmosomoides } \\
\text { polygyrus }\end{array}$} & - Mcpt8-Cre mice have a high number of eggs in feces during re-infection. & $\begin{array}{l}\text { - The fecundity of } \mathrm{Hp} \text { was increased in } \Delta \mathrm{dbIGATA} \text { and } \\
\text { PHIL mice during re-infection. }\end{array}$ & (48) \\
\hline & & & (79) \\
\hline \multirow[t]{2}{*}{ Trichinella spiralis } & - Th2 immune response is reduced in Bas-TRECK mice. & - Eosinophils increased the survival of muscle larvae & (33) \\
\hline & & & (80) \\
\hline \multirow[t]{2}{*}{ Trichuris muris } & - Basophil depletion via MAR-1 treatment increases the number of Th2 & - Eosinophil depletion by anti-IL-5 Ab treatment does not & $(54)$ \\
\hline & cells and impairs Tm expulsic & & (81) \\
\hline
\end{tabular}


control mice, but IL-5-deficient mice failed to develop blood and tissue eosinophilia in response to helminth infection (88). IL-5 transgenic (IL-5tg) mice overexpressing IL-5 in homeostatic condition have elevated numbers of circulating eosinophils, neutrophils, lymphocytes and monocytes (89).

\section{Eosinophils and Type 2 Epithelial Cytokines}

Type 2 epithelial cytokines activate ILC2 and Th2 cells to produce IL-5 and IL-13, leading to eosinophil infiltration in allergic inflammation and helminth infection $(77,90,91)$.

It has been reported that eosinophils express own receptors for Type 2 epithelial cytokines. Human eosinophils express functional TSLP receptor components: TSLPR and IL-7R $\alpha$. TSLP up-regulates the expression of adhesion molecule CD18 and intercellular adhesion molecule-1, while down-regulating Lselectin, resulting in increased migration by eosinophils to promote tissue eosinophilia (92). TSLP also induces eosinophil degranulation and the release of eosinophil extracellular traps to capture extracellular bacteria (93). Although TSLP supports the survival of various leukocytes including $\mathrm{T}$ cells and nonhematopoietic cells, the role of TSLP in maintaining eosinophil survival is controversial (94-96). Two studies examined the role of TSLP in survival of eosinophils; while one reported to enhance survival of eosinophils, the other did not report a notable change in eosinophil survival $(97,98)$. These results suggest that eosinophils are involved in pathogen defense when TSLP production is triggered by environmental factors. Furthermore, tuft cells located in mucosal epithelial layer predominantly produce IL-25 to activate ILC2 cells (99). Tuft cells monitor the microbial metabolite succinate to initiate type 2 inflammation including tuft cell and goblet cell hyperplasia, and eosinophilia (100).

\section{Eosinophil in the Skin in Helminth Infections}

Eosinophilia in the skin occurs during re-infection with Nippostrongylus brasiliensis ( $\mathrm{Nb}$ ), while $\Delta$ dblGATA mice lacking eosinophils are susceptible to re-infection of $\mathrm{Nb}$. Thus, eosinophils are believed to play an important role in providing protection during $\mathrm{Nb}$ re-infection $(101,102)$. As we mentioned above, since $\Delta$ dblGATA mice display numerical and functional aberrancy in basophils, adoptive transfer of wild-type basophils into $\triangle$ dblGATA mice confers the protective immunity against $\mathrm{Nb}$ in the skin in re-infection (20). Antibody-mediated depletion of eosinophils, with a combination of anti-IL-5 and anti-Siglec-F antibodies does not change the $\mathrm{Nb}$ parasite burden in the lungs, suggesting that basophils, rather than eosinophils, are primarily important for providing protection from $\mathrm{Nb}$ in skin in re-infection (77) (Figure 2). The role of eosinophils in the skin during Nb re-infection is not yet clear, but eosinophils have known roles in tissue repair and help the helminth infection. Eosinophils promote skin tissue repair by producing TGF- $\beta$ during the resolving phase of inflammation (103). It has been also known that eosinophils promote Trichinella spiralis (Ts) infection; eosinophils help survival of Ts larva in the muscles of hosts (104). Eosinophils increase the fecundity of Heligmosomoides polygyrus (Hp), and reduce IL- 4 response by follicular helper T cells and IgG1 classswitching in peyer's patches in re-infection (79).

\section{Eosinophils in the Lungs in Helminth Infection}

Eosinophils are recruited into $\mathrm{Nb}$-infected lungs during primary and secondary infection by ILC 2 and $\mathrm{CXCR} 6{ }^{+} \mathrm{ST} 2^{+}$memory Th2 cells $(77,82,90,105)$ (Figure $\mathbf{1}$ and Table 1). ILC2 and $\mathrm{CXCR}^{+}{ }^{+} \mathrm{ST}^{+}$memory Th2 cells express IL-33 receptors and produce high concentrations of IL-5 and IL-13 during allergic responses and parasitic infections (91, 106, 107). Eosinophildeficiency alone does not change the duration of primary $\mathrm{Nb}$ infection, but eosinophils are required to stall parasite maturation in the lung during re-infection with $\mathrm{Nb}(77,108)$. Adoptive transfer of $\mathrm{CXCR}^{+}{ }^{\mathrm{ST}} 2^{+}$memory Th2 cells from $\mathrm{Nb}$ sensitized mice conferred resistance to $\mathrm{Nb}$ in the lungs of recipient mice. IL-5 is also required to induce major basic protein (MBP) secretion by eosinophils (77). Adoptive transfer of eosinophils, but not MBP-depleted eosinophils, into the lungs inhibited $\mathrm{Nb}$ maturation. MBP expression in eosinophils is also required for eosinophils to kill Strongyloides stercoralis (Ss) parasites in implanted cell-impermeable diffusion chambers (109). Collectively, these findings suggest that eosinophils protect from $\mathrm{Nb}$ re-infection in the lungs but not skin, and that MBP produced by eosinophils is required for protection against $\mathrm{Nb}$ and $\mathrm{Ss}$.

IL-5 transgenic (IL-5tg) mice overexpressing IL-5 in homeostatic condition have elevated numbers of circulating eosinophils, neutrophils, lymphocytes and monocytes (89). Since IL-5tg mice exhibit a pronounced elevation of eosinophils, they are classically used to model chronic eosinophilia in mice. IL-5tg are strongly resistant to several helminth infections, including $\mathrm{Nb}$ and Ss $(109,110)$. Adoptive transfer of eosinophils from IL-5tg mice conferred the protection against $\mathrm{Nb}$. These imply that high levels of IL-5 confer the capacity to protect from $\mathrm{Nb}$ infection to eosinophils (111). In the same context, Yasuda et al. demonstrated that $\mathrm{Sv}$ infection prior to $\mathrm{Nb}$ infection caused mice to acquire a highly responsive "trained" phenotype. This trained phenotype was associated with a reduction in the number of $\mathrm{Nb}$ larvae in the lungs as a result of an enhanced accumulation of ILC2 cells that produced IL-5 and IL-13 to promote pulmonary eosinophilia (107).

\section{BASOPHIL, EOSINOPHILS, AND ANTIBODY PRODUCTION DURING HELMINTH INFECTION}

B cells are required for protection from various infections of nematodes including Strongyloides venezuelensis, Nippostrongylus brasiliensis (Nb), Trichuris muris and Heligmosomoides polygyrus $(48,73,74,112)$, and both basophils and eosinophils are crucial for the production and maintenance of parasite-specific antibodies during Trichinella spiraris infection (49, 80). Early evidence suggests that basophils, $\mathrm{CD}^{+} \mathrm{T}$ cells and $\mathrm{B}$ cells provide interconnecting roles in the response to parasitic infection, 


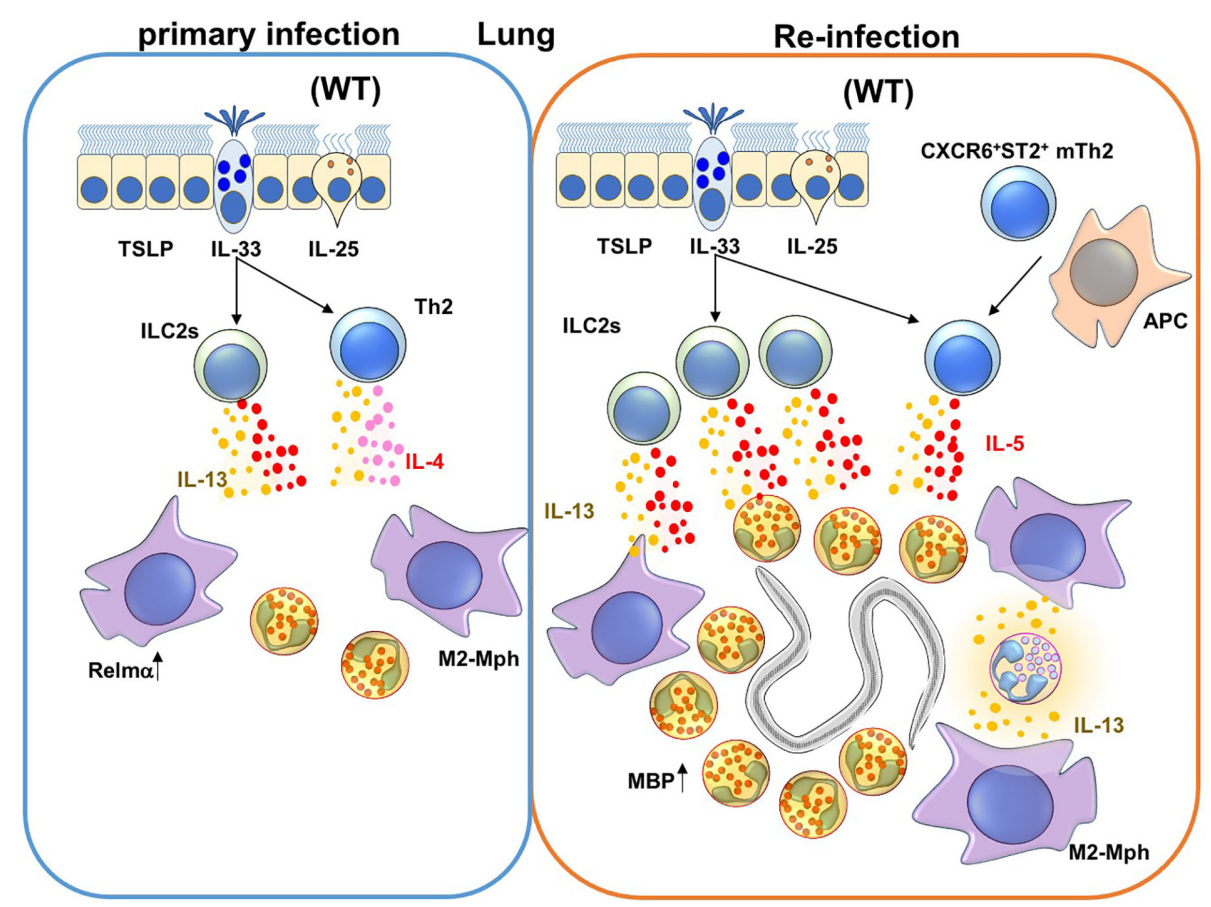

FIGURE 2 | Immune responses against Nippostrongylus brasiliensis (Nb) infection in the lungs. During a primary Nb infection, Nb leaves the lungs before the peak of infiltration of eosinophils and M2-type macrophages to the site of lung infection (68). On the other hand, during re-infection of Nb, activated Innate Lymphoid Cell 2 cells (ILC2s) and CXCR6 ${ }^{+} \mathrm{ST} 2^{+}$memory Th2 cells produce IL-5 and IL-13. IL-5 and IL-13 promote lung infiltration, activation and major basic protein (MBP) production by eosinophils. In addition, M2-type macrophages are also induced by type 2 cytokines that could be produced by ILC2s, Th2 cells and/or neutrophils in re-infection.

but the mechanisms that coordinate these cells remain poorly understood.

Activated basophils express CD40 ligand and secrete IL- 4 and IL-13, which are required for IgE class-switching and production during parasitic infection (113-116). However, this basophils activation is predominantly mediated by FceRI cross-linking (117), suggesting that the capacity for basophils to activate B cell class-switch recombination occurs after the initial priming of parasite-specific B cells. Alternatively, after co-culture with basophils, $\mathrm{CD}^{+} \mathrm{T}$ cells exhibit an augmented capacity to induce IgE class-switching in B cells (118), so basophils could also prime IgE responses through a $\mathrm{CD}^{+} \mathrm{T}$ cell intermediate. After class-switching, basophils support the survival of plasma cells and memory B cells through the production of IL- 4 and IL-6 in the spleen and bone marrow $(118,119)$, and eosinophils support the survival of plasma cells in the bone marrow through the secretion of IL-6 and APRIL (120).

IgE production relies on IL-4 production by follicular helper cells (Tfh) $(121,122)$. Tfh cells are divided into subsets by gene expression profiles and functional roles that mirror T-helper cell subsets in humans and mice; Tfh1, Tfh2, Tfh17, Tfh 13 , and follicular regulatory $\mathrm{T}$ (Tfr) cells (123-125). It has been reported that the generation of IL-4-expressing Tfh2 cells is facilitated by basophils in response to cross-linking of $\mathrm{IgD}$ on the basophil surface (126). More recently, Gowthaman et al. showed that a rare population of IL-13 producing Tfh (Tfh13) cells is required for the production of high affinity, anaphylactic IgE against allergens, whereas infection of $\mathrm{Nb}$ with OVA did not generate Tfh13 cells (125). However, Thh13-induced IgE is regulated by Tfr cells in the germinal center, suggesting that Tfr cells could be limiting Tfh 13 cells activity during $\mathrm{Nb}$ infection (127). The absence of Tfh 13 in helminth infection could explain why high affinity IgE antibodies are not detected during helminth infection.

Collectively, basophils and eosinophils have the potential to contribute to the generation of IgE specific for helminth and helmith-derived antigens, and in turn, these antibodies coat FceRI on basophils to arm them for rapid activation during reinfection of the helminth.

\section{VACCINATION AGAINST HELMINTH}

Litomosoides sigmodontis (Ls) is a filarial nematode parasite that is used as a model of filarial diseases. The parasites are inoculated or transmitted through the skin barrier by mites, and they inhabit the pleural cavity after developing into adult worms. When irradiated parasites are injected into mice as a method of vaccination, protective immunity against Ls larvae is induced in a basophildependent manner, but basophils are dispensable as effector cells against live Ls (128). Vaccination of mice with Heligmosomoides polygylus (Hp)-excretory secretory products confers the resistance against $\mathrm{Hp}$ larvae, but protective immunity depends on neutrophils, but not eosinophils, basophils or mast cells. However, basophils (but not eosinophils) do contribute to the 
worm expulsion during secondary re-infection with $\mathrm{Hp}(48,79$, 129). Killing trapped parasites in the small intestine is partially dependent on eosinophils.

The adjuvant effects of TNF- $\alpha$ have been well documented. Mast cells produced TNF- $\alpha$ to orchestrate the recruitment of T cells and dendritic cells into draining lymph nodes in Escherichia coli or Klebsiella pneumoniae infections (130). Other studies showed that TNF- $\alpha$ and synthetic granules mimicking granules of mast cells can be used for vaccination (131). Recently, Piliponsky AM et al. published that basophil-derived TNF- $\alpha$ enhanced survival in a sepsis in mice (132). Together with this, it could be possible to use basophils as one of the primary targets for vaccination as the adjuvant function.

\section{CONCLUSION}

Here, we summarized the roles of basophils and eosinophils in nematode infections. We also showed that granulocytes are stringently controlled by type 2 epithelial cytokines, and control type 2 immune responses by promoting Th2 cell differentiation and antibody production. Recent findings demonstrate that basophils and eosinophils are key players in protective immune responses against helminths. Although basophils and eosinophils are not primarily associated with directly killing nematodes during primary infection, these cells hinder parasite burden during reinfection by enacting the rapid deployment of type 2 immune responses. In response to nematode parasite re-infection, basophils are armed with $\operatorname{IgE}$ specific for nematodes or their products and accumulate in the

\section{REFERENCES}

1. Karasuyama H, Mukai K, Obata K, Tsujimura Y, Wada T. Nonredundant roles of basophils in immunity. Annu Rev Immunol (2011) 29:45-69. doi: 10.1146/annurev-immunol-031210-101257

2. Blanchard C, Rothenberg ME. Biology of the eosinophil. Adv Immunol (2009) 101:81-121. doi: 10.1016/S0065-2776(08)01003-1

3. Arinobu Y, Iwasaki H, Gurish MF, Mizuno S, Shigematsu H, Ozawa H, et al. Developmental checkpoints of the basophil/mast cell lineages in adult murine hematopoiesis. Proc Natl Acad Sci U S A (2005) 102(50):1810510. doi: 10.1073/pnas.0509148102

4. Qi X, Hong J, Chaves L, Zhuang Y, Chen Y, Wang D, et al. Antagonistic regulation by the transcription factors C/EBPalpha and MITF specifies basophil and mast cell fates. Immunity (2013) 39(1):97-110. doi: 10.1016/ j.immuni.2013.06.012

5. Mukai K, BenBarak MJ, Tachibana M, Nishida K, Karasuyama H, Taniuchi I, et al. Critical role of P1-Runx1 in mouse basophil development. Blood (2012) 120(1):76-85. doi: 10.1182/blood-2011-12-399113

6. Ohmori K, Luo Y, Jia Y, Nishida J, Wang Z, Bunting KD, et al. IL-3 induces basophil expansion in vivo by directing granulocyte-monocyte progenitors to differentiate into basophil lineage-restricted progenitors in the bone marrow and by increasing the number of basophil/mast cell progenitors in the spleen. J Immunol (2009) 182(5):2835-41. doi: 10.4049/jimmunol.0802870

7. Kitamura Y, Morii E, Jippo T, Ito A. Effect of MITF on mast cell differentiation. Mol Immunol (2002) 38(16-18):1173-6. doi: 10.1016/ s0161-5890(02)00058-5

8. Takemoto CM, Lee YN, Jegga AG, Zablocki D, Brandal S, Shahlaee A, et al. Mast cell transcriptional networks. Blood Cells Mol Dis (2008) 41(1):82-90. doi: 10.1016/j.bcmd.2008.02.005 peripheral tissues. After antigen stimulation, basophils secrete IL-4 to induce M2-type macrophages, and proteases to rapidly recruit monocytes, neutrophils, and eosinophils to the infection site. In response to IL-5, eosinophils are activated to a "trained" phenotype and produce major basic protein (MBP) to kill nematodes. On the other hand, eosinophils can also support nematode survival and tissue repair during the resolving phase. Further studies are necessary to fully characterize how basophils and eosinophils coordinate their cell-specific responses to expel nematodes. However, therapeutic targeting of basophils and eosinophils or their products could be crucial for developing novel therapeutic interventions against nematode infections.

\section{AUTHOR CONTRIBUTIONS}

KO-N, PPD and SFZ wrote the manuscript. All authors contributed to the article and approved the submitted version.

\section{FUNDING}

Support for this work was provided by NIH grants AI068731, AI125378, AI124220, and HL098067 to SFZ.

\section{ACKNOWLEDGMENTS}

We thank Y. Kurashima, K. Miyake, H. Tsutsui, and M. Iki for helpful discussion.

9. Iwasaki H, Mizuno S, Arinobu Y, Ozawa H, Mori Y, Shigematsu H, et al. The order of expression of transcription factors directs hierarchical specification of hematopoietic lineages. Genes Dev (2006) 20(21):3010-21. doi: 10.1101/ gad.1493506

10. Sasaki H, Kurotaki D, Osato N, Sato H, Sasaki I, Koizumi S, et al. Transcription factor IRF8 plays a critical role in the development of murine basophils and mast cells. Blood (2015) 125(2):358-69. doi: 10.1182/blood-2014-02-557983

11. Doyle AD, Jacobsen EA, Ochkur SI, McGarry MP, Shim KG, Nguyen DT, et al. Expression of the secondary granule proteins major basic protein 1 (MBP-1) and eosinophil peroxidase (EPX) is required for eosinophilopoiesis in mice. Blood (2013) 122(5):781-90. doi: 10.1182/blood-2013-01-473405

12. Kobayashi M, Nishikawa K, Yamamoto $M$. Hematopoietic regulatory domain of gatal gene is positively regulated by GATA1 protein in zebrafish embryos. Development (2001) 128(12):2341-50.

13. Tsai SF, Strauss E, Orkin SH. Functional analysis and in vivo footprinting implicate the erythroid transcription factor GATA-1 as a positive regulator of its own promoter. Genes Dev (1991) 5(6):919-31. doi: 10.1101/gad.5.6.919

14. Yu C, Cantor AB, Yang H, Browne C, Wells RA, Fujiwara Y, et al. Targeted deletion of a high-affinity GATA-binding site in the GATA-1 promoter leads to selective loss of the eosinophil lineage in vivo. J Exp Med (2002) 195 (11):1387-95. doi: 10.1084/jem.20020656

15. Migliaccio AR, Rana RA, Sanchez M, Lorenzini R, Centurione L, Bianchi L, et al. GATA-1 as a regulator of mast cell differentiation revealed by the phenotype of the GATA-1low mouse mutant. J Exp Med (2003) 197(3):28196. doi: 10.1084/jem.20021149

16. Akashi K, Traver D, Miyamoto T, Weissman IL. A clonogenic common myeloid progenitor that gives rise to all myeloid lineages. Nature (2000) 404 (6774):193-7. doi: 10.1038/35004599 
17. Drissen R, Buza-Vidas N, Woll P, Thongjuea S, Gambardella A, Giustacchini A, et al. Distinct myeloid progenitor-differentiation pathways identified through single-cell RNA sequencing. Nat Immunol (2016) 17(6):666-76. doi: 10.1038/ni.3412

18. Harigae H, Takahashi S, Suwabe N, Ohtsu H, Gu L, Yang Z, et al. Differential roles of GATA-1 and GATA-2 in growth and differentiation of mast cells. Genes Cells (1998) 3(1):39-50. doi: 10.1046/j.1365-2443.1998.00166.x

19. Zon LI, Yamaguchi Y, Yee K, Albee EA, Kimura A, Bennett JC, et al. Expression of mRNA for the GATA-binding proteins in human eosinophils and basophils: potential role in gene transcription. Blood (1993) 81 (12):3234-41. doi: 10.1182/blood.V81.12.3234.3234

20. Nei Y, Obata-Ninomiya K, Tsutsui H, Ishiwata K, Miyasaka M, Matsumoto $\mathrm{K}$, et al. GATA-1 regulates the generation and function of basophils. Proc Natl Acad Sci U S A (2013) 110(46):18620-5. doi: 10.1073/pnas.1311668110

21. Hussain M, Borcard L, Walsh KP, Pena Rodriguez M, Mueller C, Kim BS, et al. Basophil-derived IL-4 promotes epicutaneous antigen sensitization concomitant with the development of food allergy. J Allergy Clin Immunol (2018) 141(1):223-34 e5. doi: 10.1016/j.jaci.2017.02.035

22. Sharma S, Tomar S, Dharne M, Ganesan V, Smith A, Yang Y, et al. Deletion of DeltadblGata motif leads to increased predisposition and severity of IgEmediated food-induced anaphylaxis response. PLoS One (2019) 14(8): e0219375. doi: 10.1371/journal.pone.0219375

23. Ohneda K, Moriguchi T, Ohmori S, Ishijima Y, Satoh H, Philipsen S, et al. Transcription factor GATA1 is dispensable for mast cell differentiation in adult mice. Mol Cell Biol (2014) 34(10):1812-26. doi: 10.1128/ MCB.01524-13

24. Sasaki H, Kurotaki D, Tamura T. Regulation of basophil and mast cell development by transcription factors. Allergol Int (2016) 65(2):127-34. doi: 10.1016/j.alit.2016.01.006

25. Obata K, Mukai K, Tsujimura Y, Ishiwata K, Kawano Y, Minegishi Y, et al. Basophils are essential initiators of a novel type of chronic allergic inflammation. Blood (2007) 110(3):913-20. doi: 10.1182/blood-2007-01068718

26. Ito Y, Satoh T, Takayama K, Miyagishi C, Walls AF, Yokozeki H. Basophil recruitment and activation in inflammatory skin diseases. Allergy (2011) 66 (8):1107-13. doi: 10.1111/j.1398-9995.2011.02570.x

27. Wada $\mathrm{T}$, Ishiwata $\mathrm{K}$, Koseki $\mathrm{H}$, Ishikura $\mathrm{T}$, Ugajin $\mathrm{T}$, Ohnuma N, et al. Selective ablation of basophils in mice reveals their nonredundant role in acquired immunity against ticks. J Clin Invest (2010) 120(8):2867-75. doi: 10.1172/JCI42680

28. Nakahigashi K, Otsuka A, Tomari K, Miyachi Y, Kabashima K. Evaluation of basophil infiltration into the skin lesions of tick bites. Case Rep Dermatol (2013) 5(1):48-51. doi: 10.1159/000348650

29. Ohta T, Yoshikawa S, Tabakawa Y, Yamaji K, Ishiwata K, Shitara H, et al. Skin CD4(+) Memory T Cells Play an Essential Role in Acquired AntiTick Immunity through Interleukin-3-Mediated Basophil Recruitment to Tick-Feeding Sites. Front Immunol (2017) 8:1348. doi: 10.3389/ fimmu.2017.01348

30. Mitre E, Nutman TB. Lack of basophilia in human parasitic infections. Am J Trop Med Hyg (2003) 69(1):87-91. doi: 10.4269/ajtmh.2003.69.87

31. Shen T, Kim S, Do JS, Wang L, Lantz C, Urban JF, et al. T cell-derived IL-3 plays key role in parasite infection-induced basophil production but is dispensable for in vivo basophil survival. Int Immunol (2008) 20(9):12019. doi: $10.1093 /$ intimm/dxn077

32. Hida S, Yamasaki S, Sakamoto Y, Takamoto M, Obata K, Takai T, et al. Fc receptor gamma-chain, a constitutive component of the IL-3 receptor, is required for IL-3-induced IL-4 production in basophils. Nat Immunol (2009) 10(2):214-22. doi: 10.1038/ni.1686

33. Giacomin PR, Siracusa MC, Walsh KP, Grencis RK, Kubo M, Comeau MR, et al. Thymic stromal lymphopoietin-dependent basophils promote Th2 cytokine responses following intestinal helminth infection. J Immunol (2012) 189(9):4371-8. doi: 10.4049/jimmunol.1200691

34. Herbst T, Esser J, Prati M, Kulagin M, Stettler R, Zaiss MM, et al. Antibodies and IL-3 support helminth-induced basophil expansion. Proc Natl Acad Sci U S A (2012) 109(37):14954-9. doi: 10.1073/pnas.1117584109

35. Hill DA, Siracusa MC, Abt MC, Kim BS, Kobuley D, Kubo M, et al. Commensal bacteria-derived signals regulate basophil hematopoiesis and allergic inflammation. Nat Med (2012) 18(4):538-46. doi: 10.1038/nm.2657
36. Kitaura J, Song J, Tsai M, Asai K, Maeda-Yamamoto M, Mocsai A, et al. Evidence that IgE molecules mediate a spectrum of effects on mast cell survival and activation via aggregation of the FcepsilonRI. Proc Natl Acad Sci U S A (2003) 100(22):12911-6. doi: 10.1073/pnas.1735525100

37. Xiang Z, Moller C, Nilsson G. IgE-receptor activation induces survival and Bfl-1 expression in human mast cells but not basophils. Allergy (2006) 61 (9):1040-6. doi: 10.1111/j.1398-9995.2006.01024.x

38. Ziegler SF, Artis D. Sensing the outside world: TSLP regulates barrier immunity. Nat Immunol (2010) 11(4):289-93. doi: 10.1038/ni.1852

39. Kondo Y, Yoshimoto T, Yasuda K, Futatsugi-Yumikura S, Morimoto M, Hayashi N, et al. Administration of IL-33 induces airway hyperresponsiveness and goblet cell hyperplasia in the lungs in the absence of adaptive immune system. Int Immunol (2008) 20(6):791-800. doi: 10.1093/intimm/dxn037

40. Imai $Y$, Yasuda K, Nagai M, Kusakabe M, Kubo M, Nakanishi K, et al. IL-33Induced Atopic Dermatitis-Like Inflammation in Mice Is Mediated by Group 2 Innate Lymphoid Cells in Concert with Basophils. J Invest Dermatol (2019) 139(10):2185-94.e3. doi: 10.1016/j.jid.2019.04.016

41. Sherrill JD, Gao PS, Stucke EM, Blanchard C, Collins MH, Putnam PE, et al. Variants of thymic stromal lymphopoietin and its receptor associate with eosinophilic esophagitis. J Allergy Clin Immunol (2010) 126(1):160-5 e3. doi: 10.1016/j.jaci.2010.04.037

42. Venturelli N, Lexmond WS, Ohsaki A, Nurko S, Karasuyama H, Fiebiger E et al. Allergic skin sensitization promotes eosinophilic esophagitis through the IL-33-basophil axis in mice. J Allergy Clin Immunol (2016) 138(5):136780 e5. doi: 10.1016/j.jaci.2016.02.034

43. Noti M, Wojno ED, Kim BS, Siracusa MC, Giacomin PR, Nair MG, et al. Thymic stromal lymphopoietin-elicited basophil responses promote eosinophilic esophagitis. Nat Med (2013) 19(8):1005-13. doi: 10.1038/ nm. 3281

44. Han H, Roan F, Johnston LK, Smith DE, Bryce PJ, Ziegler SF. IL-33 promotes gastrointestinal allergy in a TSLP-independent manner. Mucosal Immunol (2018) 11(2):394-403. doi: 10.1038/mi.2017.61

45. Kim BS, Wang K, Siracusa MC, Saenz SA, Brestoff JR, Monticelli LA, et al. Basophils promote innate lymphoid cell responses in inflamed skin. $J$ Immunol (2014) 193(7):3717-25. doi: 10.4049/jimmunol.1401307

46. Schwartz C, Eberle JU, Hoyler T, Diefenbach A, Lechmann M, Voehringer D. Opposing functions of thymic stromal lymphopoietin-responsive basophils and dendritic cells in a mouse model of atopic dermatitis. $J$ Allergy Clin Immunol (2016) 138(5):1443-6 e8. doi: 10.1016/ j.jaci.2016.04.031

47. Kabata H, Flamar AL, Mahlakoiv T, Moriyama S, Rodewald HR, Ziegler SF, et al. Targeted deletion of the TSLP receptor reveals cellular mechanisms that promote type 2 airway inflammation. Mucosal Immunol (2020) 13:62636. doi: 10.1038/s41385-020-0266-x

48. Schwartz C, Turqueti-Neves A, Hartmann S, Yu P, Nimmerjahn F, Voehringer D. Basophil-mediated protection against gastrointestinal helminths requires IgE-induced cytokine secretion. Proc Natl Acad Sci U S A (2014) 111(48):E5169-77. doi: 10.1073/pnas.1412663111

49. Torrero MN, Hubner MP, Larson D, Karasuyama H, Mitre E. Basophils amplify type 2 immune responses, but do not serve a protective role, during chronic infection of mice with the filarial nematode Litomosoides sigmodontis. J Immunol (2010) 185(12):7426-34. doi: 10.4049/ jimmunol.0903864

50. Anthony RM, Urban JFJr., Alem F, Hamed HA, Rozo CT, Boucher JL, et al. Memory $\mathrm{T}(\mathrm{H}) 2$ cells induce alternatively activated macrophages to mediate protection against nematode parasites. Nat Med (2006) 12(8):955-60. doi: $10.1038 / \mathrm{nm} 1451$

51. Hida S, Tadachi M, Saito T, Taki S. Negative control of basophil expansion by IRF-2 critical for the regulation of Th1/Th2 balance. Blood (2005) 106 (6):2011-7. doi: 10.1182/blood-2005-04-1344

52. Otsuka A, Nakajima S, Kubo M, Egawa G, Honda T, Kitoh A, et al. Basophils are required for the induction of Th2 immunity to haptens and peptide antigens. Nat Commun (2013) 4:1739. doi: 10.1038/ ncomms 2740

53. Tang H, Cao W, Kasturi SP, Ravindran R, Nakaya HI, Kundu K, et al. The T helper type 2 response to cysteine proteases requires dendritic cell-basophil cooperation via ROS-mediated signaling. Nat Immunol (2010) 11(7):608-17. doi: $10.1038 /$ ni. 1883 
54. Perrigoue JG, Saenz SA, Siracusa MC, Allenspach EJ, Taylor BC, Giacomin $\mathrm{PR}$, et al. MHC class II-dependent basophil-CD4+ T cell interactions promote $\mathrm{T}(\mathrm{H}) 2$ cytokine-dependent immunity. Nat Immunol (2009) 10 (7):697-705. doi: 10.1038/ni.1740

55. Sokol CL, Chu NQ, Yu S, Nish SA, Laufer TM, Medzhitov R. Basophils function as antigen-presenting cells for an allergen-induced T helper type 2 response. Nat Immunol (2009) 10(7):713-20. doi: 10.1038/ni.1738

56. Yoshimoto T, Yasuda K, Tanaka H, Nakahira M, Imai Y, Fujimori Y, et al. Basophils contribute to $\mathrm{T}(\mathrm{H}) 2$-IgE responses in vivo via IL-4 production and presentation of peptide-MHC class II complexes to CD4+ T cells. Nat Immunol (2009) 10(7):706-12. doi: 10.1038/ni.1737

57. Tang XZ, Jung JB. Allen CDC. A case of mistaken identity: The MAR-1 antibody to mouse FcepsilonRIalpha cross-reacts with FcgammaRI and FcgammaRIV. J Allergy Clin Immunol (2019) 143(4):1643-6 e6. doi: 10.1016/j.jaci.2018.11.045

58. Hammad H, Plantinga M, Deswarte K, Pouliot P, Willart MA, Kool M, et al. Inflammatory dendritic cells-not basophils-are necessary and sufficient for induction of Th2 immunity to inhaled house dust mite allergen. J Exp Med (2010) 207(10):2097-111. doi: 10.1084/jem.20101563

59. Bosteels C, Neyt K, Vanheerswynghels M, van Helden MJ, Sichien D, Debeuf $\mathrm{N}$, et al. Inflammatory Type $2 \mathrm{cDCs}$ Acquire Features of $\mathrm{cDC} 1 \mathrm{~s}$ and Macrophages to Orchestrate Immunity to Respiratory Virus Infection. Immunity (2020) 52(6):1039-56.e9. doi: 10.1016/j.immuni.2020.04.005

60. Miyake K, Shiozawa N, Nagao T, Yoshikawa S, Yamanishi Y, Karasuyama H. Trogocytosis of peptide-MHC class II complexes from dendritic cells confers antigen-presenting ability on basophils. Proc Natl Acad Sci U S A (2017) 114 (5):1111-6. doi: 10.1073/pnas.1615973114

61. Pellefigues C, Mehta P, Prout MS, Naidoo K, Yumnam B, Chandler J, et al. The Basoph8 Mice Enable an Unbiased Detection and a Conditional Depletion of Basophils. Front Immunol (2019) 10:2143. doi: 10.3389/ fimmu.2019.02143

62. Satoh T, Nakagawa K, Sugihara F, Kuwahara R, Ashihara M, Yamane F, et al. Identification of an atypical monocyte and committed progenitor involved in fibrosis. Nature (2017) 541(7635):96-101. doi: 10.1038/nature20611

63. Webb LM, Oyesola OO, Fruh SP, Kamynina E, Still KM, Patel RK, et al. The Notch signaling pathway promotes basophil responses during helminthinduced type 2 inflammation. J Exp Med (2019) 216(6):1268-79. doi: $10.1084 /$ jem. 20180131

64. Inclan-Rico JM, Ponessa JJ, Valero-Pacheco N, Hernandez CM, Sy CB, Lemenze $\mathrm{AD}$, et al. Basophils prime group 2 innate lymphoid cells for neuropeptide-mediated inhibition. Nat Immunol (2020) 21(10):1181-93. doi: 10.1038/s41590-020-0753-y

65. Egawa M, Mukai K, Yoshikawa S, Iki M, Mukaida N, Kawano Y, et al. Inflammatory monocytes recruited to allergic skin acquire an antiinflammatory M2 phenotype via basophil-derived interleukin-4. Immunity (2013) 38(3):570-80. doi: 10.1016/j.immuni.2012.11.014

66. Bonne-Annee S, Kerepesi LA, Hess JA, O'Connell AE, Lok JB, Nolan TJ, et al. Human and mouse macrophages collaborate with neutrophils to kill larval Strongyloides stercoralis. Infect Immun (2013) 81(9):3346-55. doi: 10.1128/IAI.00625-13

67. Chen F, Wu W, Millman A, Craft JF, Chen E, Patel N, et al. Neutrophils prime a long-lived effector macrophage phenotype that mediates accelerated helminth expulsion. Nat Immunol (2014) 15(10):938-46. doi: 10.1038/ ni.2984

68. Krljanac B, Schubart C, Naumann R, Wirtz S, Culemann S, Kronke G, et al. RELMalpha-expressing macrophages protect against fatal lung damage and reduce parasite burden during helminth infection. Sci Immunol (2019) 4(35): eaau3814. doi: 10.1126/sciimmunol.aau3814

69. Ohnmacht C, Schwartz C, Panzer M, Schiedewitz I, Naumann R, Voehringer D. Basophils orchestrate chronic allergic dermatitis and protective immunity against helminths. Immunity (2010) 33(3):364-74. doi: 10.1016/ j.immuni.2010.08.011

70. Ohnmacht C, Voehringer D. Basophil effector function and homeostasis during helminth infection. Blood (2009) 113(12):2816-25. doi: 10.1182/ blood-2008-05-154773

71. Ohnmacht C, Voehringer D. Basophils protect against reinfection with hookworms independently of mast cells and memory Th2 cells. $J$ Immunol (2010) 184(1):344-50. doi: 10.4049/jimmunol.0901841
72. Sullivan BM, Liang HE, Bando JK, Wu D, Cheng LE, McKerrow JK, et al. Genetic analysis of basophil function in vivo. Nat Immunol (2011) 12 (6):527-35. doi: 10.1038/ni.2036

73. Obata-Ninomiya K, Ishiwata K, Tsutsui H, Nei Y, Yoshikawa S, Kawano Y, et al. The skin is an important bulwark of acquired immunity against intestinal helminths. J Exp Med (2013) 210(12):2583-95. doi: 10.1084/ jem.20130761

74. Matsumoto M, Sasaki Y, Yasuda K, Takai T, Muramatsu M, Yoshimoto T, et al. IgG and IgE collaboratively accelerate expulsion of Strongyloides venezuelensis in a primary infection. Infect Immun (2013) 81(7):2518-27. doi: 10.1128/IAI.00285-13

75. Mukai K, Karasuyama H, Kabashima K, Kubo M, Galli SJ. Differences in the Importance of Mast Cells, Basophils, IgE, and IgG versus That of CD4(+) T Cells and ILC2 Cells in Primary and Secondary Immunity to Strongyloides venezuelensis. Infect Immun (2017) 85(5):e00053-17. doi: 10.1128/ IAI.00053-17

76. Reitz M, Brunn ML, Voehringer D, Breloer M. Basophils are dispensable for the establishment of protective adaptive immunity against primary and challenge infection with the intestinal helminth parasite Strongyloides ratti. PLoS Negl Trop Dis (2018) 12(11):e0006992. doi: 10.1371/ journal.pntd.0006992

77. Obata-Ninomiya K, Ishiwata K, Nakano H, Endo Y, Ichikawa T, Onodera A, et al. CXCR6(+)ST2(+) memory T helper 2 cells induced the expression of major basic protein in eosinophils to reduce the fecundity of helminth. Proc Natl Acad Sci U S A (2018) 115(42):E9849-E58. doi: 10.1073/ pnas. 1714731115

78. Ovington KS, McKie K, Matthaei KI, Young IG, Behm CA. Regulation of primary Strongyloides ratti infections in mice: a role for interleukin-5. Immunology (1998) 95(3):488-93. doi: 10.1046/j.1365-2567. 1998.00620.x

79. Strandmark J, Steinfelder S, Berek C, Kuhl AA, Rausch S, Hartmann S. Eosinophils are required to suppress Th2 responses in Peyer's patches during intestinal infection by nematodes. Mucosal Immunol (2017) 10 (3):661-72. doi: 10.1038/mi.2016.93

80. Huang L, Gebreselassie NG, Gagliardo LF, Ruyechan MC, Luber KL, Lee NA, et al. Eosinophils mediate protective immunity against secondary nematode infection. J Immunol (2015) 194(1):283-90. doi: 10.4049/ jimmunol.1402219

81. Betts CJ, Else KJ. Mast cells, eosinophils and antibody-mediated cellular cytotoxicity are not critical in resistance to Trichuris muris. Parasite Immunol (1999) 21(1):45-52. doi: 10.1046/j.1365-3024.1999.00200.x

82. Bouchery T, Kyle R, Camberis M, Shepherd A, Filbey K, Smith A, et al. ILC2s and $\mathrm{T}$ cells cooperate to ensure maintenance of M2 macrophages for lung immunity against hookworms. Nat Commun (2015) 6:6970. doi: 10.1038/ ncomms7970

83. Iki M, Tanaka K, Deki H, Fujimaki M, Sato S, Yoshikawa S, et al. Basophil tryptase mMCP-11 plays a crucial role in IgE-mediated, delayed-onset allergic inflammation in mice. Blood (2016) 128(25):2909-18. doi: 10.1182/blood-2016-07-729392

84. Tsutsui H, Yamanishi Y, Ohtsuka H, Sato S, Yoshikawa S, Karasuyama H. The Basophil-specific Protease mMCP-8 Provokes an Inflammatory Response in the Skin with Microvascular Hyperpermeability and Leukocyte Infiltration. J Biol Chem (2017) 292(3):1061-7. doi: 10.1074/ jbc.M116.754648

85. Dvorak AM, Letourneau L, Login GR, Weller PF, Ackerman SJ. Ultrastructural localization of the Charcot-Leyden crystal protein (lysophospholipase) to a distinct crystalloid-free granule population in mature human eosinophils. Blood (1988) 72(1):150-8. doi: 10.1182/ blood.V72.1.150.150

86. Rosenberg HF, Phipps S, Foster PS. Eosinophil trafficking in allergy and asthma. J Allergy Clin Immunol (2007) 119(6):1303-10; quiz 11-2. doi: 10.1016/j.jaci.2007.03.048

87. Persson EK, Verstraete K, Heyndrickx I, Gevaert E, Aegerter H, Percier JM, et al. Protein crystallization promotes type 2 immunity and is reversible by antibody treatment. Science (2019) 364(6442):eaaw4295. doi: 10.1126/ science.aaw4295

88. Kopf M, Brombacher F, Hodgkin PD, Ramsay AJ, Milbourne EA, Dai WJ, et al. IL-5-deficient mice have a developmental defect in CD5+ B-1 cells and 
lack eosinophilia but have normal antibody and cytotoxic $\mathrm{T}$ cell responses. Immunity (1996) 4(1):15-24. doi: 10.1016/s1074-7613(00)80294-0

89. Dent LA, Strath M, Mellor AL, Sanderson CJ. Eosinophilia in transgenic mice expressing interleukin 5. J Exp Med (1990) 172(5):1425-31. doi: $10.1084 /$ jem.172.5.1425

90. Yasuda K, Muto T, Kawagoe T, Matsumoto M, Sasaki Y, Matsushita K, et al. Contribution of IL-33-activated type II innate lymphoid cells to pulmonary eosinophilia in intestinal nematode-infected mice. Proc Natl Acad Sci U S A (2012) 109(9):3451-6. doi: 10.1073/pnas.1201042109

91. Endo Y, Hirahara K, Iinuma T, Shinoda K, Tumes DJ, Asou HK, et al. The interleukin-33-p38 kinase axis confers memory $\mathrm{T}$ helper 2 cell pathogenicity in the airway. Immunity (2015) 42(2):294-308. doi: 10.1016/ j.immuni.2015.01.016

92. Noh JY, Shin JU, Park CO, Lee N, Jin S, Kim SH, et al. Thymic stromal lymphopoietin regulates eosinophil migration via phosphorylation of 1 plastin in atopic dermatitis. Exp Dermatol (2016) 25(11):880-6. doi: $10.1111 /$ exd.13111

93. Cook EB, Stahl JL, Schwantes EA, Fox KE, Mathur SK. IL-3 and TNFalpha increase Thymic Stromal Lymphopoietin Receptor (TSLPR) expression on eosinophils and enhance TSLP-stimulated degranulation. Clin Mol Allergy (2012) 10(1):8. doi: 10.1186/1476-7961-10-8

94. Wang Q, Du J, Zhu J, Yang X, Zhou B. Thymic stromal lymphopoietin signaling in CD4(+) T cells is required for TH2 memory. J Allergy Clin Immunol (2015) 135(3):781-91 e3. doi: 10.1016/j.jaci.2014.09.015

95. Rochman Y, Leonard WJ. The role of thymic stromal lymphopoietin in CD8 + T cell homeostasis. J Immunol (2008) 181(11):7699-705. doi: 10.4049/ jimmunol.181.11.7699

96. Kuan EL, Ziegler SF. A tumor-myeloid cell axis, mediated via the cytokines IL-1alpha and TSLP, promotes the progression of breast cancer. Nat Immunol (2018) 19(4):366-74. doi: 10.1038/s41590-018-0066-6

97. Wong CK, Hu S, Cheung PF, Lam CW. Thymic stromal lymphopoietin induces chemotactic and prosurvival effects in eosinophils: implications in allergic inflammation. Am J Respir Cell Mol Biol (2010) 43(3):305-15. doi: 10.1165/rcmb.2009-0168OC

98. Morshed M, Yousefi S, Stockle C, Simon HU, Simon D. Thymic stromal lymphopoietin stimulates the formation of eosinophil extracellular traps. Allergy (2012) 67(9):1127-37. doi: 10.1111/j.1398-9995.2012.02868.x

99. von Moltke J, Ji M, Liang HE, Locksley RM. Tuft-cell-derived IL-25 regulates an intestinal ILC2-epithelial response circuit. Nature (2016) 529(7585):2215. doi: 10.1038/nature16161

100. Nadjsombati MS, McGinty JW, Lyons-Cohen MR, Jaffe JB, DiPeso L, Schneider C, et al. Detection of Succinate by Intestinal Tuft Cells Triggers a Type 2 Innate Immune Circuit. Immunity (2018) 49(1):33-41 e7. doi: 10.1016/j.immuni.2018.06.016

101. Knott ML, Matthaei KI, Giacomin PR, Wang H, Foster PS, Dent LA. Impaired resistance in early secondary Nippostrongylus brasiliensis infections in mice with defective eosinophilopoeisis. Int J Parasitol (2007) 37(12):1367-78. doi: 10.1016/j.ijpara.2007.04.006

102. Huang L, Appleton JA. Eosinophils in Helminth Infection: Defenders and Dupes. Trends Parasitol (2016) 32(10):798-807. doi: 10.1016/ j.pt.2016.05.004

103. Levi-Schaffer F, Garbuzenko E, Rubin A, Reich R, Pickholz D, Gillery P, et al. Human eosinophils regulate human lung- and skin-derived fibroblast properties in vitro: a role for transforming growth factor beta (TGF-beta). Proc Natl Acad Sci U S A (1999) 96(17):9660-5. doi: 10.1073/pnas.96. 17.9660

104. Huang L, Beiting DP, Gebreselassie NG, Gagliardo LF, Ruyechan MC, Lee NA, et al. Eosinophils and IL-4 Support Nematode Growth Coincident with an Innate Response to Tissue Injury. PLoS Pathog (2015) 11(12):e1005347. doi: 10.1371/journal.ppat.1005347

105. Hung LY, Lewkowich IP, Dawson LA, Downey J, Yang Y, Smith DE, et al. IL33 drives biphasic IL-13 production for noncanonical Type 2 immunity against hookworms. Proc Natl Acad Sci U S A (2013) 110(1):282-7. doi: 10.1073/pnas.1206587110

106. Yamamoto T, Endo Y, Onodera A, Hirahara K, Asou HK, Nakajima T, et al. DUSP10 constrains innate IL-33-mediated cytokine production in ST2(hi) memory-type pathogenic Th2 cells. Nat Commun (2018) 9(1):4231. doi: $10.1038 / \mathrm{s} 41467-018-06468-8$
107. Yasuda K, Adachi T, Koida A, Nakanishi K. Nematode-Infected Mice Acquire Resistance to Subsequent Infection With Unrelated Nematode by Inducing Highly Responsive Group 2 Innate Lymphoid Cells in the Lung. Front Immunol (2018) 9:2132. doi: 10.3389/fimmu.2018.02132

108. Voehringer D, Reese DA, Huang X, Shinkai K, Locksley RM. Type 2 immunity is controlled by IL-4/IL-13 expression in hematopoietic noneosinophil cells of the innate immune system. J Exp Med (2006) 203 (6):1435-46. doi: 10.1084/jem.20052448

109. O'Connell AE, Hess JA, Santiago GA, Nolan TJ, Lok JB, Lee JJ, et al. Major basic protein from eosinophils and myeloperoxidase from neutrophils are required for protective immunity to Strongyloides stercoralis in mice. Infect Immun (2011) 79(7):2770-8. doi: 10.1128/IAI.00931-10

110. Herbert DR, Lee JJ, Lee NA, Nolan TJ, Schad GA, Abraham D. Role of IL-5 in innate and adaptive immunity to larval Strongyloides stercoralis in mice. J Immunol (2000) 165(8):4544-51. doi: 10.4049/jimmunol.165.8.4544

111. Shin EH, Osada Y, Chai JY, Matsumoto N, Takatsu K, Kojima S. Protective roles of eosinophils in Nippostrongylus brasiliensis infection. Int Arch Allergy Immunol (1997) 114(Suppl 1):45-50. doi: 10.1159/000237717

112. Blackwell NM, Else KJ. B cells and antibodies are required for resistance to the parasitic gastrointestinal nematode Trichuris muris. Infect Immun (2001) 69(6):3860-8. doi: 10.1128/IAI.69.6.3860-3868.2001

113. Gauchat JF, Henchoz S, Mazzei G, Aubry JP, Brunner T, Blasey H, et al. Induction of human IgE synthesis in B cells by mast cells and basophils. Nature (1993) 365(6444):340-3. doi: 10.1038/365340a0

114. Morawetz RA, Gabriele L, Rizzo LV, Noben-Trauth N, Kühn R, Rajewsky K, et al. Interleukin (IL)-4-independent immunoglobulin class switch to immunoglobulin (Ig)E in the mouse. J Exp Med (1996) 184(5):1651-61. doi: 10.1084 /jem.184.5.1651

115. Punnonen J, Yssel H, de Vries JE. The relative contribution of IL-4 and IL-13 to human IgE synthesis induced by activated CD4+ or CD8+ T cells. J Allergy Clin Immunol (1997) 100(6 Pt 1):792-801. doi: 10.1016/s0091-6749(97) 70276-8

116. Fish SC, Donaldson DD, Goldman SJ, Williams CM, Kasaian MT. IgE generation and mast cell effector function in mice deficient in IL-4 and IL-13. J Immunol (2005) 174(12):7716-24. doi: 10.4049/jimmunol.174.12.7716

117. Gibbs BF, Haas H, Falcone FH, Albrecht C, Vollrath IB, Noll T, et al. Purified human peripheral blood basophils release interleukin-13 and preformed interleukin-4 following immunological activation. Eur J Immunol (1996) 26 (10):2493-8. doi: 10.1002/eji.1830261033

118. Denzel A, Maus UA, Rodriguez Gomez M, Moll C, Niedermeier M, Winter $\mathrm{C}$, et al. Basophils enhance immunological memory responses. Nat Immunol (2008) 9(7):733-42. doi: 10.1038/ni.1621

119. Rodriguez Gomez M, Talke Y, Goebel N, Hermann F, Reich B, Mack M. Basophils support the survival of plasma cells in mice. J Immunol (2010) 185 (12):7180-5. doi: 10.4049/jimmunol.1002319

120. Chu VT, Fröhlich A, Steinhauser G, Scheel T, Roch T, Fillatreau S, et al. Eosinophils are required for the maintenance of plasma cells in the bone marrow. Nat Immunol (2011) 12(2):151-9. doi: 10.1038/ni.1981

121. Harada Y, Tanaka S, Motomura Y, Harada Y, Ohno S, Ohno S, et al. The 3' enhancer CNS2 is a critical regulator of interleukin-4-mediated humoral immunity in follicular helper T cells. Immunity (2012) 36(2):188-200. doi: 10.1016/j.immuni.2012.02.002

122. Crotty $\mathrm{S}$. T follicular helper cell differentiation, function, and roles in disease. Immunity (2014) 41(4):529-42. doi: 10.1016/j.immuni.2014.10.004

123. Wing JB, Ise W, Kurosaki T, Sakaguchi S. Regulatory T cells control antigenspecific expansion of Tfh cell number and humoral immune responses via the coreceptor CTLA-4. Immunity (2014) 41(6):1013-25. doi: 10.1016/ j.immuni.2014.12.006

124. Ueno H, Banchereau J, Vinuesa CG. Pathophysiology of T follicular helper cells in humans and mice. Nat Immunol (2015) 16(2):142-52. doi: 10.1038/ ni. 3054

125. Gowthaman U, Chen JS, Zhang B, Flynn WF, Lu Y, Song W, et al. Identification of a $\mathrm{T}$ follicular helper cell subset that drives anaphylactic IgE. Science (2019) 365(6456):eaaw6433. doi: 10.1126/science.aaw6433

126. Shan M, Carrillo J, Yeste A, Gutzeit C, Segura-Garzon D, Walland AC, et al. Secreted IgD Amplifies Humoral T Helper 2 Cell Responses by Binding Basophils via Galectin-9 and CD44. Immunity (2018) 49(4):709-24 e8. doi: 10.1016/j.immuni.2018.08.013 
127. Clement RL, Daccache J, Mohammed MT, Diallo A, Blazar BR, Kuchroo VK, et al. Follicular regulatory $\mathrm{T}$ cells control humoral and allergic immunity by restraining early B cell responses. Nat Immunol (2019) 20(10):1360-71. doi: 10.1038/s41590-019-0472-4

128. Torrero MN, Morris CP, Mitre BK, Hubner MP, Fox EM, Karasuyama H, et al. Basophils help establish protective immunity induced by irradiated larval vaccination for filariasis. Vaccine (2013) 31(36):3675-82. doi: 10.1016/ j.vaccine.2013.06.010

129. Hewitson JP, Filbey KJ, Esser-von Bieren J, Camberis M, Schwartz C, Murray J, et al. Concerted activity of IgG1 antibodies and IL-4/IL-25dependent effector cells trap helminth larvae in the tissues following vaccination with defined secreted antigens, providing sterile immunity to challenge infection. PLoS Pathog (2015) 11(3):e1004676. doi: 10.1371/ journal.ppat.1004676

130. Kurashima Y, Kiyono H. New era for mucosal mast cells: their roles in inflammation, allergic immune responses and adjuvant development. Exp Mol Med (2014) 46:e83. doi: 10.1038/emm.2014.7
131. St John AL, Chan CY, Staats HF, Leong KW, Abraham SN. Synthetic mastcell granules as adjuvants to promote and polarize immunity in lymph nodes. Nat Mater (2012) 11(3):250-7. doi: 10.1038/nmat3222

132. Piliponsky AM, Shubin NJ, Lahiri AK, Truong P, Clauson M, Niino K, et al. Basophil-derived tumor necrosis factor can enhance survival in a sepsis model in mice. Nat Immunol (2019) 20(2):129-40. doi: 10.1038/s41590-018-0288-7

Conflict of Interest: The authors declare that the research was conducted in the absence of any commercial or financial relationships that could be construed as a potential conflict of interest.

Copyright (c) 2020 Obata-Ninomiya, Domeier and Ziegler. This is an open-access article distributed under the terms of the Creative Commons Attribution License (CC BY). The use, distribution or reproduction in other forums is permitted, provided the original author(s) and the copyright owner(s) are credited and that the original publication in this journal is cited, in accordance with accepted academic practice. No use, distribution or reproduction is permitted which does not comply with these terms. 